\title{
Pentingnya Sistem Manajemen dan Struktur Organisasi dalam Suatu Usaha
}

\author{
Febe Ziphora \\ Program Studi Kewirausahaan \\ Universitas Bina Nusantara \\ febe.ziphora@binus.ac.id
}

Suatu struktur organisasi merupakan suatu sistem yang berfungsi untuk merinci berjalannya aktivitas dan kegiatan tertentu yang akan didelegasikan guna mencapai tujuan sebuah organisasi. Dengan menguraikan setiap peran karyawan atau pegawai ke berbagai tanggung jawab dalam perusahaan (Indeed, 2021). Kegiatan ini dapat mencakup aturan, peran, dan tanggung jawab. Semakin banyak kepercayaan atau otoritas yang dimiliki oleh seorang karyawan, maka semakin tinggi posisi atau kedudukan mereka dalam struktur organisasi. Selain itu, memiliki struktur organisasi memungkinkan semakin terorganisir suatu struktur, semakin efisien suatu perusahaan beroperasi (Investopedia, 2021). Cara yang paling efektif untuk menggambarkan bagaimana sebuah perusahaan akan terstruktur dan garis wewenang dan pertanggungjawaban yang akan diterapkan adalah mencakup dengan membuat bagan organisasi dalam rencana (Barringer, 2015). Walaupun tidak semua bisnis mengimplementasikan struktur organisasi, akan tetapi struktur organisasi memiliki banyak manfaat bagi suatu organisasi atau perusahaan yang menerapkannya, yaitu pengambilan keputusan dapat lebih cepat dilakukan, memiliki beberapa lokasi bisnis yang tersebar, kegiatan operasional akan semakin efisien, menghasilkan kinerja karyawan yang lebih baik, menghindari duplikasi pekerjaan, mengurangi konflik yang timbul dalam karyawan, dan mampu menghasilkan komunikasi yang lebih baik (Indeed, 2021).

Strategi merupakan rencana untuk bertindak mencapai tujuan dan sasaran yang harus memperhatikan berbagai kekuatan, kelemahan, peluang, dan ancaman yang didasarkan pada faktor kemampuan, posisi, persaingan, pelanggan, dan faktor luas baik ekonomi maupun teknologi (Purnomo et al., 2020). Untuk menetapkan strateginya, dalam suatu struktur organisasi terdapat perincian tim, yaitu salah satunya tim manajemen. Tim manajemen sebuah perusahaan baru biasanya terdiri dari pendiri itu sendiri dan beberapa personel manajemen kunci atau personel penting dalam suatu usaha tersebut, perusahaan tahap awal tersebut akan berencana untuk menambahkan personel baru tambahan (Barringer, 2015).

Titik awal untuk setiap desain atau bagan organisasi adalah struktur perusahaan yang realistis dengan didasarkan pada strategi yang dipikirkan secara matang. Jika tim manajemen mengembangkan strategi yang dipahami dengan jelas dan struktur 
perusahaan mudah untuk mengakomodasinya, maka sistem manajemen tersebut dapat dikatakan akan memiliki peluang yang lebih baik untuk menjadi efektif (Tiller, 2012). Perusahaan perlu untuk melakukan perencanaan, melakukan diskusi, dan juga menetapkan peran yang tepat dan jelas demi menghasilkan kepemimpinan yang sukses, terutama yang diwujudkan dalam sistem manajemen, selama menjalankan bisnis. Pengoperasian dan penggunaan sistem manajemen juga harus didokumentasikan dan disebarkan ke seluruh perusahaan supaya seluruh karyawan dapat mengetahui dengan baik bagian apa yang mereka miliki yang harus segera mereka kerjakan (Crossan et al., 2005).

\section{References}

Barringer, B. R. (2015). Preparing Effective Business Plans: An Entrepreneurial Approach (2nd ed.). Pearson Education Limited.

https://www.pearson.com/us/higher-education/program/Barringer-PreparingEffective-Business-Plans-An-Entrepreneurial-Approach-2ndEdition/PGM168007.html

Crossan, M. M., Rowe, W. G., \& Maurer, C. C. (2005). Strategic Analysis and Action. Pearson Education, Inc.

Indeed. (2021). Org Structure: Definition, Types and Tips. Indeed. https://www.indeed.com/career-advice/career-development/org-structure Investopedia. (2021). Organizational Structure. Investopedia. https://www.investopedia.com/terms/o/organizational-structure.asp

Purnomo, A., Sudirman, A., Hasibuan, A., Sudarso, A., Sahir, S. H., Salmiah, Mastuti, R., Chamidah, D., Koryati, T., \& Simarmata, J. (2020). Dasar-Dasar Kewirausahaan: untuk Perguruan Tinggi dan Dunia Bisnis. Yayasan Kita Menulis. https://kitamenulis.id/2020/04/06/dasar-dasar-kewirausahaan-untuk-perguruantingi-dan-dunia-bisnis/

Tiller, S. R. (2012). Organizational Structure and Management Systems. Leadership and Management in Engineering, 12(1), 20-23. https://doi.org/10.1061/(ASCE)LM.1943-5630.0000160 


\section{Biografi}

\section{Febe Ziphora}

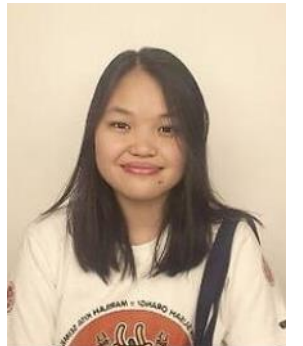

Penulis kelahiran Sukoharjo ini merupakan seorang mahasiswa program studi kewirausahaan di Universitas Bina Nusantara, kampus Malang sejak tahun 2020. Febe sedang menjalankan studi dan sedang mengembangkan ide bisnis Caker Café yaitu bisnis café yang menjual berbagai macam pattiseries dan beverages, yang bergerak di industri makanan dan minuman. Penggemar film dan musik ini memiliki prinsip hidup bahwa "dirimu sendirilah yang memutuskan siapa dirimu yang sebenarnya" .

Email: febe.ziphora@binus.ac.id

Instagram: @febe_oei

Linkedin: www.linkedin.com/in/febe-ziphora-7a2502143

URL: https://httpaliencrush.wordpress.com/ 